\title{
Alanya Otel İşletmelerinde AHP Metodu ile Tedarikçi Seçimi
}

\author{
Supplier Selection with AHP Method in Alanya Hotel Establishments \\ Mehmet GÜMÜŞ \\ Doç. Dr. Alanya Alaaddin Keykubat Üniversitesi, Mühendislik Fakültesi, Endüstri Mühendisliği Bölümü \\ mehmet.gumus@alanya.edu.tr
}

\author{
Ayşe Nur KARABAYIR \\ Arş. Gör. Alanya Alaaddin Keykubat Üniversitesi, Mühendislik Fakültesi, Endüstri Mühendisliği Bölümü \\ ayse.karabayir@alanya.edu.tr
}

Tuğçe GÜLER

tugce_guler13@hotmail.com

Gözde ARSLAN

gozde_arslan_@hotmail.com

\section{Anahtar kelimeler: \\ Tedarikçi Seçimi \\ Tedarik Zinciri \\ Analitik Hiyerarşi \\ Prosesi}

\section{ÖZET}

Tedarikçi secimi, alternatif tedarikçiler arasından firmanın beklentileri göz önüne alınarak en uygun olanının belirlenmesidir. Müşteri memnuniyetinin önemli olduğu otellerde tedarikçi secimi, birçok seçme kriteri olmasından dolayı zor bir problemdir. Bu çalışmada çok kriterli karar verme yöntemlerinden biri olan Analitik Hiyerarşi Prosesi (AHP) ile otel işletmelerinde tedarikçi secimi yapılmıştır. Literatür çalışması ve uzman görüşlerine dayanılarak tedarikçi seçiminde kullanılan 6 ana kriter belirlenmiştir. Kriterlerin öncelik sırası ve ă̆ırlıkları ikili karşılaştırma matrisleri kullanılarak bulunmuştur. Çalışmanın uygulaması Alanya bölgesindeki biri 4 yıldızlı, diğeri 5 yıldızlı olan iki farklı otelde yapılmıştır. Çalışma sonucunda aynı sektörde yer almasına rağmen farkl hizmet düzeyine sahip olmalarından dolayı iki farkl otelde kriterlerin önem sıralamasının farklı olduğu görülmüştür. Yerel tedarikçilerle çalışan 4 yıldızlı otelin ilk iki önceliğinin sırasıly kalite ve esneklik olduğu bulunmuştur. Ulusal tedarikçilerle çalışan 5 yıldızlı otelin ilk iki önceliğinin ise strastyla fiyat ve kalite olduğu belirlenmiştir.

\section{ABSTRACT}

Supplier selection is the identification of the most suitable supplier among alternative suppliers while considering the expectations of the firm. Supplier selection at hotels, where customer satiffaction is important, is a difficult problem since there are many selection criteria. In tis study, supplier selection in hotel establishments is performed using Analytical Hyrarchy Proess (AHP) which is one of the multi criteria decision making methods. Based on literature study and expert opinions, six main criteria used in supplier selection are identified. Priorities and weights of the criteria are found using pairwise comparison matrices. Application of the study is performed at two different hotels, one being a 4-star and the other being a 5-star, in Alanya district. It is seen that importance ranking of the criteria at the two hotels are different since the hotels have different customer service, eventhough they both are located in the same sector. The first two priorities for the 4-star hotel, which works with local suppliers, are quality and flexibility, respectively. On the other hand, the first two prioroties of the 5 star hotel, which works with national suppliers, are price and quality, respectively. 


\section{Gİiș}

Günümüzün değişen ekonomik koşulları ve teknolojik ilerlemeler ile gelen küreselleşme, sektör farkı gözetmeksizin firmaların başarı için rekabet üstünlüğü sağlamalarını gerektirmektedir. Bu üstünlüğü sağlamak da pazarda oluşturulan farklılıkla ortaya çıkacaktır. Farklılı̆̆ı sağlamanın alternatiflerinden önemli bir tanesi tedarik zincirini etkin olarak yönetmektir. Tedarik zinciri yönetimi, hammaddenin temin edilmesinden ürünün nihai kullanıcıya ulaşmasına kadar geçen sürecin yönetilmesini kapsar. Tedarikçiler, bu zinciri oluşturan en önemli elemanlardandır. Her işletme kendi beklentileri doğrultusunda kendilerine en uygun tedarikçilerle çalışmak ister. Bu beklentiler işletmenin belirlediği misyon ve vizyon çerçevesinde belirlenir. Pazarda rekabet halinde bulunan alternatif tedarikçiler bu beklentileri farklı ölçülerde karşılarlar. Tedarikçi seçimi bundan dolayı zincirin sağlamlığı açısından fazlasıyla önem arz eder.

Hizmet sektöründe doğru tedarikçilerin seçimi hizmet kalitesini artırmak için gereklidir. Bu sektörde yer alan otel işletmeleri için müşteri memnuniyeti, hizmet kalitesinin yansıra tedarikçilerden temin edilen ürünlerin satın alma süreçlerinin doğru yönetilmesine de bağlıdır. Doğru tedarikçilerden yapılan alımlar müşterilerin talep ettiği fiyat ve kalite avantajlarını oluşturmak adına önemlidir. Alternatif tedarikçiler arasından doğru seçimi yapmak ise birçok seçme kriterinin bulunmasından dolayı karmaşık bir hale gelebilir. Bu çalışmanın amacı dört ve beş yıldızlı oteller için raf ömrü sınırlı ürün tedarikçilerinin çok kriterli karar verme tekniklerinden biri olan Analitik Hiyerarşi Prosesi(AHP) metodu ile belirlenmesidir. İki farklı otelde yapılan uygulama çalışması, otel işletmelerinin tedarikçi seçme kriterlerini belirlemelerinde yardımcı olacaktır.

\section{TEDARIK ZINCİRI YÖNETIMİ ve TEDARÍKÇİ SEÇIMII}

\subsection{Tedarik Zinciri Yönetimi}

Turgut (2015), tedarik zincirini, "Hammaddelerin temin edilmesinden başlayıp müşteriye teslim edilmesine kadar geçen süreçte yer alan tedarikçiler, imalatçılar, perakendeciler ve müşterilerden oluşur. Bu grup, güçlü bir iletişim ile kaynakları etkin bir şekilde kullanarak müşteri isteklerine verimli bir şekilde cevap vermek, maliyetleri azaltmak, üretim ve dağıtımda hızlı ve esnek bir tedariki gerçekleştirmek amacını güder." olarak belirtmiştir.

Tedarik zinciri yönetimi, tüm iş süreçlerini birbirinden ayrılmaz halkalar olarak düşünmektedir. Müşteri ilişkileri yönetimi, satış, üretim, satın alma ve tedarikçi ilişkileri yönetimi zincirin birer halkası olarak tanımlanmaktadır. Sistem, bu halkaları bir bütün olarak görmekte ve halkaların toplam başarısını ölçmektedir (Şen, 2006). Böylece süreçlerin bütünlüğünü sağlanır ve birimler arası sinerji oluşturularak toplam faydalar maksimize edilebilir.

Tedarik zinciri ve yönetimi kavramları işletmelerce etkin bir biçimde anlaşılmalı ve uygulamaya konulmalıdır. Bunun sonucunda işletmelerde karlılık artacak, maliyet açısından etkinlik sağlanacak ve en önemlisi müşterilere sunulacak olan ürün ve hizmet kalitesi ve değerinde önemli artışlar olacaktır (Erdem, 2003). Günümüzde işletmeler, artan rekabet ortamında üretimlerini sürdürmek zorundadır. Bu ortamda işletmelerin tutunabilmesi için kalite ve servis hizmetlerini yükseltmeleri gerekmektedir. İşletmeler pazarda sahip oldukları payı korumak veya paylarını artırmak için sadece kendi bünyelerinde çalışma yapmanın yetersiz olduğunu ve işletmeler arası ilişkilerin önemini anlamıştır. Bu anlamda işletmeler, gerek tedarikçileri ile gerekse müşterileriyle olan ilişkilerini tekrar gözden geçirip karşılıklı işbirliği ve değer yaratma esasına göre yeniden yapılanmaya başlamıştır. Tedarikçilerle işbirliği yapılması ve bunun sürekli geliştirilmesi sonucunda ürün kalitesi üzerindeki olumlu bir etki meydana gelmiş, satın alınan ürünlerin maliyetinde düşüş gözlenmiş, üretimde esneklik artmış ve bunların neticesinde müşteri memnuniyetinde artış meydana gelmişstir (Kapar, 2013).

\subsection{Tedarikçi Seçimi}

Tedarik, gereksinim duyulan bir ürün ya da hizmetin istenilen zamanda, doğru şekilde, doğru miktarda ve uygun maliyet ile temin edilmesidir. İşletmeler günümüz şartlarında varlıklarını sürdürebilmek ve zarar etmemek için toplam maliyetin içerisinde çok yüksek orana sahip olan satın alma maliyetlerini düşürmek zorundadır. İşletmelerin üretim ve malzeme maliyetlerine etki eden satın alma maliyelerini azaltmak için ürün ve/veya hizmet tedarik sürecine odaklanmaları 
gerekmiştir. Bunun sonucu olarak tedarikçi seçimi problemleri ortaya çıkmış ve işletmeler açısından önemli hale gelmiştir (Karagöz, 2009).

İşletmelerin, istedikleri özelliklerdeki ürünleri üretme yeteneğine sahip tedarikçiler arasından hangi tedarikçi ya da tedarikçilerin seçileceğine karar verilmesi süreci tedarikçi seçim problemi olarak tanımlanmaktadır. Tedarikçi seçimi, işletmelerin ihtiyaç duyduğu hammadde, yarı mamul ve diğer malzemelerin kimden alınacağının belirlenmesidir. Tedarikçi seçiminin amacı bir işletmenin ihtiyaç duyduğu ürünleri istenilen miktarlarda, uygun fiyattan ve kaliteli olarak temin edebilecekleri tedarikçileri belirlemektir (Güner, 2005).

Tedarikçi seçimi; amacın belirlenmesi, seçme kriterlerinin tanımlanması, uygun tedarikçiler arasında ön değerlendirme yapılması ve nihai seçimin yapılması olarak dört aşamada ele alınabilir. Tedarikçi seçiminde amaç seçim yapılacak olan sektöre ve bu sektörün pazar önceliklerine göre belirlenir. Amaç belirlendikten sonra bu amaca ulaşılması için uygun kriterler belirlenir (Ecer ve Küçük, 2008). Kriterler, her işletmeye ya da sektöre göre değişiklik gösterebilir ve işletmenin ihtiyaçlarını, ileriye dönük stratejilerini yansıtacak şekilde belirlenmelidir. Yapılacak olan karşılaştırmaların tutarlı ve objektif olabilmesi için tüm tedarikçileri kapsayacak şekilde ortak kriterlerin belirlenmesi önem arz etmektedir (Güner ve Mutlu, 2005). Belirlenen kriterlere göre amaç göz önüne alınarak değerlendirme yapılır ve nihai olarak tedarikçi belirlenir. Tedarikçi seçimi, hem işletmenin çalışacağı tedarikçi sayısının belirlenmesi, hem de var olan tedarikçiler arasından en uygununun seçilmesi olmak üzere iki farklı yönden de ele alınabilmektedir (Benyoucef vd, 2003).

\subsubsection{Tedarikçi Seçim Kriterleri}

Yapılmış çalışmalara bakıldığında tedarikçi seçiminde veya değerlendirilmesinde üç ana kriter söz konusudur. Bunlar fiyat, kalite ve teslimattır (Öz ve Baykoç, 2004). Bunlara ilave olarak müşteri memnuniyeti, esneklik, satış sonrası hizmet gibi kriterler de tedarikçilerin değerlendirilmesinde kullanılmaktadır. Bazı araştırmacılara göre, tedarikçi performansı ile ilgili müşteri memnuniyeti kriterleri çeşitli ölçütleri içermektedir. Bunlardan bazılar; ürün yelpazesi, ürün kalitesi, ürün desteği, müşteri servisinin etkinliği, fiyatlandırma, teslimat performansı vb. olarak sıralanabilir (Abdulmumin, 2005).

Parahinski ve Benton (2004), tedarikçi performansını kritik başarı faktörü olarak görmektedir. Yani, tedarikçi performansının üretici firmayı direkt etkilediği ve kritik bir etmen olduğu görülmektedir. Bu açıdan inceledikleri zaman kriterleri; ürün kalitesi, teslimat performansı, fiyat, değişen isteklere cevap verme, servis desteği ve genel performans olarak belirlemişlerdir. Liu ve Hai (2005) ise, tedarikçi seçimi probleminde 8 ana kritere göre değerlendirme yapmıştır. Bu kriterler; kalite, hızlı cevap verebilme, disiplin, teslimat, finans, yönetim, teknik kapasite ve tesis olarak belirlenmiştir.

Tedarikçi seçimi problemlerinde çok sayıda nitel ve nicel kriter göz önünde bulundurulmalıdır. Dickson (1966), 273 işletmeyle yaptığı anket sonucunda tedarikçileri değerlendirmek için 23 kriter önermiştir. Bu kriterler Tablo 2.1'de önem sırasına göre verilmektedir.

Tablo 2.1. Tedarikçi değerlendirme kriterleri (Dickson 1966)

\begin{tabular}{|l|l|l|l|}
\hline Sıra & Kriter & Sıra & Kriter \\
\hline 1 & Kalite & 13 & Yönetim ve organizasyon \\
\hline 2 & Teslimat & 14 & İşletim maliyetleri \\
\hline 3 & Performans & 15 & Tamir hizmetleri \\
\hline 4 & Garanti ve şikayet politikaları & 16 & Tedarikçi tavırları \\
\hline 5 & Üretim tesisi ve kapasitesi & 17 & Etki \\
\hline 6 & Fiyat & 18 & Ambalajlama Kabiliyeti \\
\hline 7 & Teknik açıdan yeterlilik & 19 & Çalışanlarının kayıtlarının tutulması \\
\hline 8 & Finansal durum & 20 & Coğrafik konum \\
\hline 9 & Prosedürlere uyma & 21 & Geçmiş işlerin durumu \\
\hline 10 & İletişim & 22 & Eğitim \\
\hline 11 & Sanayideki durum & 23 & Karşılıklı anlaşmalar \\
\hline 12 & İş için istekli olma & & \\
\hline
\end{tabular}


Weber vd. (1991) çalışmalarında, 1966 - 1990 yılları arasında tedarikçi seçimi üzerine yapılmış 74 makaleyi incelemişler ve tedarikçi seçimi problemlerinde kullanılan kriterlerin ve bunların kullanım oranlarını bulmayı hedeflemişlerdir. Çalışmaları sonucunda en çok kullanılan kriterler sırasıyla; net fiyat $(\% 80)$, teslimat $(\% 58)$ ve kalite $(\% 53)$ olarak belirlenmiştir.

Roa ve Keiser (1980) tedarikçi seçimiyle ilgili yapmış oldukları çalışmalarında, Dickson'ın çalışmasından farklı olarak seçimi etkileyen 60 kriter olduğunu tespit etmişlerdir. Geçen 14 yıl içinde tedarikçi seçim kriterlerine 37 yeni kriter eklenmesi tedarikçi seçim sürecinin gelişimini gözler önüne sermektedir. Bu süreç içinde teknolojinin gelişmesi, artan müşteri istekleri vb. çok sayıda faktör tedarikçilerden beklentileri de arttırmıştır ve sonuçta Dickson'un kriterlerine ürün tasarımından yedek parçaya kadar çok çeşitli alanlarda yeni kriterler eklenmiştir.

\section{ANALITIKK HIYYERARŞI PROSESI}

Analitik Hiyerarşi Prosesi (AHP), 1970 yılında Thomas L. Saaty tarafından kıt kaynakların dağılımı ve askeri ihtiyaçların karşılanması amaçlarıyla geliştirilmiştir ve o tarihten itibaren literatürde yer alan birçok araştırmada kullanılmıştır (Çakıroğlu, 2009).

AHP, çok kriterli karar verme problemlerinde ögelerin öncelik durumunu belirlemeye, kriterler ve alternatifler arasındaki öncelik ve ilişki durumunu hiyerarşik bir yapı içerisinde göstermeye yarayan sistematik bir yöntemdir. AHP, problemi küçük parçalara ayırır, ikili karşılaştırmalar yapar, her hiyerarşi için öncelikleri belirler ve böylece belli bir mantıksal süreci düzenler (Saat, 2000). AHP ile karar vericiler kompleks yapıdaki problemleri, ana hedeften alt kriterlere kadar hiyerarşik bir yapı içinde gösterebilmektedir (Ada vd, 2005).

AHP ile bir problem çözüleceği zaman izlenecek adımlar aşağıdaki gibidir (Yu vd, 2011):

- AHP yapısını oluşturma

- İkili karşıllaştırma matrislerinin oluşturulması

- Kriterlerin ağırlıklarını hesaplama

- Tutarlılık testinin yapilması

\subsection{AHP Yapısını Oluşturma}

AHP; amaç, kriterler ve alternatiflerden meydana gelen hiyerarşik bir yapıya sahiptir. Bu yapının en üst bölümünde esas amaç, orta seviyelerde kriterler, en altta ise alternatifler bulunmaktadır ( $\mathrm{Yu} \mathrm{vd,} \mathrm{2011).} \mathrm{Bu} \mathrm{adım} \mathrm{sürecin} \mathrm{en} \mathrm{önemli}$ aşamasıdır. Karar probleminin ne olduğu, hangi ölçütlere göre değerlendirileceği ve seçenekler bu adımda belirlenmektedir. Ölçütlerin doğru olarak belirlenmesi verilecek kararların doğruluğu açısından çok önemlidir. Çünkü seçeneklerin ölçütlerinin doğru bir şekilde seçilmesi, karar vericinin amacına en uygun seçimi yapmasını sağlayacaktır (Özer, 2005).

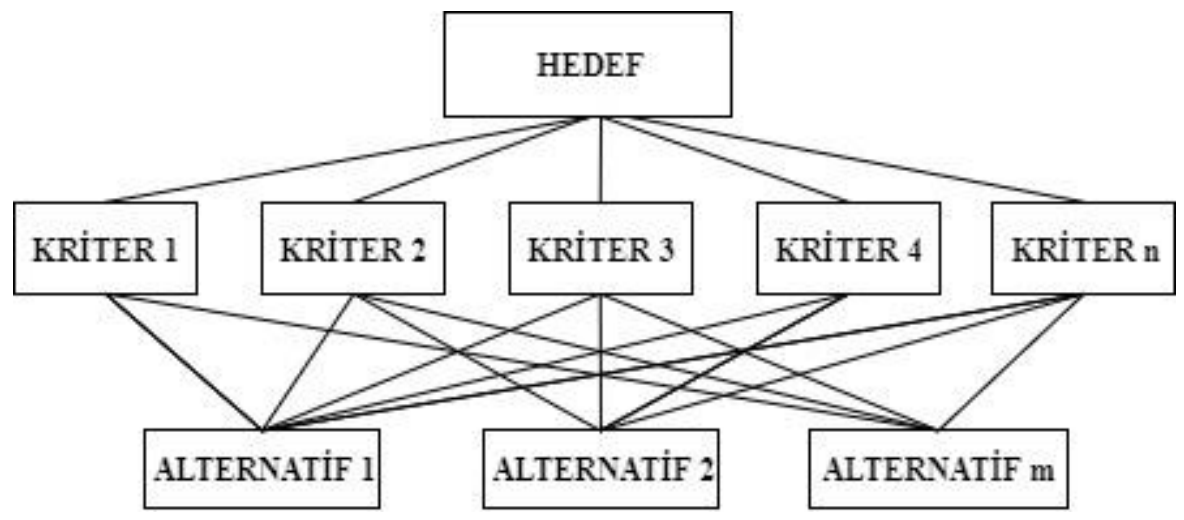


Bir hiyerarşi tasarımının ayrıntılı bir şekilde belirlenmesi için takip edilmesi gereken yol şu şekildedir (Topel, 2006):

- Genel amacin belirlenmesi (Temel sorunun ortaya koyulmasi),

- Genel amaca ait alt amaçların belirlenmesi,

- Belirlenen alt amaçları gerçekleştirmede uyulması gereken kriterlerin belirlenmesi,

- Her bir kriterin alt kriterlerinin belirlenmesi,

- Problemle ilgili kişilerin veya grubun belirlenmesi,

- Bu kişi ve grupların amaçları ve politikalarının belirlenmesi,

- Sonuçların ya da alternatiflerin belirlenmesi,

- En fazla tercih edilen kararın seçilmesinin ve seçilmemesinin getireceği, yarar ve maliyetlerin karşılaştırılması,

- Fayda maliyet analizinin yapılmasıdır.

\section{2. İkili Karşılaştırma Matrislerinin Oluşturulması}

İkinci aşamada kriterlerin birbirlerine göre önem dereceleri karşılaştırılır ve daha yüksek öneme sahip kriter esas alınır (Yu vd., 2011). AHP uygulanması esnasında konuyla ilgili yetkin kişilerden birebir anket çalışması ya da mülakat aracılığıyla görüşleri alınır. Sonuçların tutarlılığı için kişiler konularında uzman ya da konu hakkında orta derecede bilgili olmalıdır. AHP'nin sonuçları tamamen bu kişilerin yapacağı karşılaştırma değerlerine bağlıdır. Bu değerler kullanılarak ikili karşılaştırma matrisi oluşturulur.

Karar kriterlerinin ve karar seçeneklerinin ikili karşılaştırması için Thomas L. Saaty bir ölçek geliştirmiştir. Bu ölçekte her bir karar kriterinin ikili karşılaştırması ve karar seçeneklerinin bu karar kriterine göre ikili karşılaştırmaları 1 ile 9 arasında bir değerle ölçülmektedir (Dündar, 2008). Tablo 3.1. de bu değerlerin ikili karşılaştırmadaki anlamları verilmiştir.

Tablo 3.1. İkili Karşılaştırmalarda Kullanılan Değerlerin Anlamları (Saaty, 2000)

\begin{tabular}{|c|c|c|}
\hline $\begin{array}{l}\text { Rakamsal } \\
\text { Değerler }\end{array}$ & $\begin{array}{l}\text { Karşılığı } \quad \text { (Önem } \\
\text { Düzeyi) }\end{array}$ & Açıklama \\
\hline 1 & Eşit & İki yargı aynı derecede önem taşımaktadır. \\
\hline 3 & Daha Önemli & İki yargıdan biri diğerine göre orta derecede önem taşımaktadır. \\
\hline 5 & $\begin{array}{l}\text { Kuvvetli Derecede } \\
\text { önemli }\end{array}$ & $\begin{array}{l}\text { İki yargıdan biri diğerine göre kuvvetli derecede önem } \\
\text { taşımaktadır. }\end{array}$ \\
\hline 7 & $\begin{array}{l}\text { Çok Kuvvetli } \\
\text { Derecede Önemli }\end{array}$ & $\begin{array}{l}\text { İki yargıdan biri diğerine göre çok kuvvetli derecede önem } \\
\text { taşımaktadır. }\end{array}$ \\
\hline 9 & $\begin{array}{l}\text { Aşırı Derecede } \\
\text { Önemli }\end{array}$ & İki yargıdan biri diğerine göre aşırı derecede önem taşımaktadır. \\
\hline $2,4,6,8$ & Ara Değerler & $\begin{array}{l}\text { İki yargı arasında kararsız kalındığında ve tercih değerleri } \\
\text { birbirine cok yakın olduğunda kullanılmaktadır. }\end{array}$ \\
\hline
\end{tabular}

Hiyerarşi sürecinde alternatiflerin birbirlerine göre önem düzeylerini belirleyebilmek için her alternatifin diğer alternatiflerle yukarıdaki tabloda bulunan önem dereceleri göz önüne alınarak puanlanır (Küçük ve Ecer, 2008).

AHP'de yargılar ikili karşılaştırmalar ile nxn boyutlu bir kare bir matrise dönüştürülür. i ve j özelliklerin ikili karşılaştırma değerini verecek olursa aij ikili karşılaştırma matrisi şu şekilde yazılır (Eraslan ve Algün, 2005): 


$$
A=\left|\begin{array}{cccc}
a_{11} & a_{12} & \ldots & a_{1 n} \\
a_{21} & a_{22} & \ldots & a_{2 n} \\
\cdot & & & \cdot \\
\cdot & & & \cdot \\
\cdot & & & \cdot \\
a_{n 1} & a_{n 2} & \ldots & a_{n n}
\end{array}\right|
$$

\subsection{Kriterlerin Ağırlıklarının Hesaplanması}

n>5 olduğu durumda öz vektörün bulunması için geometrik ortalama kullanılır. Öncelikle her satırdaki n adet eleman birbiriyle çarpılır ve n. Dereceden kökü alınır. Oluşan bu yeni vektör normalleştirilir (Alioğlu, 2006).

$$
b_{i j}=\frac{a_{i j}}{\sum_{i=1}^{n} a_{i j}} \quad B_{i=}\left|\begin{array}{ccccc}
b_{11} & b_{12} & b_{13} & \ldots & b_{1 n} \\
b_{21} & b_{22} & b_{23} & \ldots & b_{2 n} \\
\cdot & & & & \cdot \\
\cdot & & & & . \\
b_{1 n} & b_{2 n} & b_{3 n} & \ldots & b_{n n}
\end{array}\right|
$$

Normalleştirilmiş bu matris kullanılarak her bir satırdaki değerler toplanır ve matrisin boyutuna bölünerek her bir kriter için yüzde olarak önem ağırlıkları belirlenir (Toksarı, 2007).

$$
W_{i}=\frac{\sum_{j=1}^{n} c_{i j}}{n}
$$

$$
W=\left|\begin{array}{c}
w_{1} \\
w_{2} \\
\cdot \\
\cdot \\
w_{n}
\end{array}\right|
$$

\subsection{Tutarlılık Testinin Yapılması}

AHP uygulamalarında son olarak karar vericinin ikili karşılaştırmalar esnasında tutarlı davranıp davranmadığı ve son kararın güvenirliği için tutarlılık testi yapılır. Hesaplanan tutarlılık oranı değeri 0,10 'a eşit veya küçük ise karar vericinin verdiği kararlar tutarlıdır. Büyük olması durumu karar vericinin karşılaştırmalardaki tutarsızlığını ya da hesaplama hatası olduğunu gösterir. Böyle bir durumda karar verici karşıllaştırma değerlerini tekrar gözden geçirmelidir (Özgül, 2006).

Tutarlılık testi aşağıdaki şekilde yapılmaktadır. İkili karşılaştırma matrisi ile daha önce hesaplanan göreli ağırlık derecesi çarpılarak yeni vektör elde edilir. 


$$
\mathrm{D}=\left|\begin{array}{cccc}
a_{11} & a_{12} & \ldots & a_{1 n} \\
a_{21} & a_{22} & \ldots & a_{2 n} \\
\cdot & & & \cdot \\
\cdot & & & \cdot \\
\cdot & & & \cdot \\
a_{n 1} & a_{n 2} & \ldots & a_{n n}
\end{array}\right| \times\left|\begin{array}{c}
w_{1} \\
w_{2} \\
\cdot \\
\cdot \\
\cdot \\
w_{n}
\end{array}\right|
$$

Bulunan ağırlıklı toplam vektörün elemanları kendisine karşılık gelen göreli ağırlık derecesine bölünür. Son olarak vektörün elemanları toplanır ve aritmetik ortalaması alınır. Elde edilen sonuç en büyük öz değeri $\left(\lambda_{\max }\right)$ verir (Ömürbek ve Şimşek, 2012).

$$
E_{i}=\frac{d_{i}}{W_{i}} \quad \lambda=\frac{\sum_{i=1}^{n} E_{i}}{n}
$$

$\lambda_{\max }$ kullanılarak tutarlılık göstergesi (CI) hesaplanır (Ömürbek ve Şimşek, 2012).

$$
C I=\frac{\lambda_{\max }-n}{n-1}
$$

Tutarlılık oranı (CR) tutarlılık göstergesinin rassallık göstergesine (RI) oranıyla bulunur (Ömürbek ve Şimşek, 2012).

$$
C R=\frac{C I}{R I}
$$

Rassallık göstergeleri yapılan çalışmalar sonucunda elde edilmiş sabit değerlerdir ve rassallık göstergeleri Tablo 3.2'de yer almaktadır.

Tablo 3.2. Rassallık Göstergeleri (Ömürbek ve Şimşek, 2012)

\begin{tabular}{|l|l|l|l|l|l|l|l|l|l|l|l|l|l|l|l|}
\hline $\mathrm{N}$ & 1 & 2 & 3 & 4 & 5 & 6 & 7 & 8 & 9 & 10 & 11 & 12 & 13 & 14 & 15 \\
\hline $\mathrm{RI}$ & 0 & 0 & 0,58 & 0,90 & 1,12 & 1.24 & 1,32 & 1,41 & 1,45 & 1,49 & 1,51 & 1,48 & 1,56 & 1,57 & 1,59 \\
\hline
\end{tabular}

\section{ALANYA OTEL İŞLETMELERINDE UYGULAMA}

Turizm sektöründe birçok 4 ve 5 yıldızlı otel sundukları konaklama hizmetiyle beraber müşterilerine yeme-içme hizmeti de sunmaktadır. $\mathrm{Bu}$ otellerin diğerlerine nazaran kaliteli hizmet vermek ve bunu sürekli geliştirme isteğine ek olarak maliyetlere verdikleri önemden dolayı otellerin gıda tedarikçileri büyük önem taşımaktadır. 4 ve 5 yıldızlı otellerde müşterilerin memnuniyet beklentisi yüksek olduğundan bu işletmelerin alternatifler tedarikçiler arasından en uygun seçimi yapmaları zor bir karar sürecidir. Bu çalışmanın uygulama kısmında, Alanya hizmet sektöründe yer alan otel işletmelerinde gıda tedarikçisi seçimi yapılmıştır. İlk aşamada, tedarikçi seçiminde karşılaştırma ve değerlendirme yapılacak kriterlerin belirlenmesi için literatür araştırması yapılmışıır.

Literatür taramasından sonra elde edilen kriterler Alanya ve çevresinde bulunan 4 ya da 5 yıldızlı otellerdeki satın alma yöneticileri veya genel müdürlerle yüz yüze mülakatlar ile otel işletmelerine uygun olarak aşağıdaki şekilde belirlenmiştir:

- Esneklik: Ürün miktarında esneklik, ürün çeşitliliği, acil taleplere karşl1ık verilmesi, ve üründe istenilen değişimlerin karşılanabilmesini kapsar.

- Fiyat: Ürün için ödenen fiyattır. 
- Kalite: Ürünün niteliklerine uygun olması, kusurlu ürün oranı, ürünün tesliminde iç ve dış sıcaklığın uygunluğu, tedarikçinin kalite sertifikası olup olmadığı, satış sonrası destek, tedarikçinin ilgi düzeyi ve ürün ambalajlamasının yapılmasını içerir.

- Profil: Tedarikçinin markalaşmış bir firma olup olmadığını ölçer.

- Tedarikçi ilişkileri: Tedarikçi ile iletişim kurma kolaylığ çözüm odaklı olup olmadığını belirler.

- Teslimat: Ürünün doğru miktarda, istenilen zamanda, teslimat şartnamesine uygun olarak ve doğru yere teslimatı kapsar. Aynı zamanda raf ömrü olan ürünler için nakliye araçlarının uygunluğunu içerir.

Çalışmada, 4 yıldızlı ve 5 yıldızlı olmak üzere iki ayrı işletmede tedarikçi seçimi uygulaması yapılmıştır. Uygulama yapılan otellerden 5 yıldızlı olanı, Alanya'nın yaklaşık $5 \mathrm{~km}$ doğusunda yer almakta olup 800 yatak kapasitelidir. Bu otel için alternatif gıda tedarikçileri üç adet olarak otelin satın alma müdürü tarafindan belirlenmiştir. Çalışmada Alternatif $5^{*} 1$, Alternatif $5 * 2$ ve Alternatif $5 * 3$ olarak adlandırılan bu tedarikçilerin genel bilgileri şu şekildedir:

- Alternatif 5*1: Ağırlıklı olarak Akdeniz bölgesinde bilinen ve gıda sektöründe markalaşmış üretici bir firmadır.

- Alternatif $5 * 2$ : Ulusal düzeyde bilinen ve gıda sektöründe markalaşmış üretici bir firmadır.

- Alternatif $5 * 3$ : İstanbul merkezli olup gıda sektöründe toptan satış yapan bir firmadır. Antalya'da satış temsilciliği bulunmaktadir.

Uygulamanın gerçekleştirildiği diğer otel Alanya merkezde yer alan 4 yıldızlı bir otel olup 350 yatak kapasitelidir. Bu otelin alternatif gıda tedarikçileri otel satın alma birimi tarafından üç adet olarak belirlenmiştir. Çalışmada Alternatif $4 * 1$, Alternatif $4 * 2$ ve Alternatif $4 * 3$ olarak adlandırılan bu tedarikçilerin genel bilgileri şu şekildedir:

- Alternatif 4*1: Otellerin ihtiyaçlarına yönelik gıda ürünleri ve sevk hizmeti sunmaktadır ve Antalya'da bulunmaktadır.

- Alternatif 4*2: Türkiye'nin çeşitli illerinde toptan satış konseptiyle çalışan ve Alanya'da şubesi bulunan bir firmadır.

- Alternatif 4*3: Alanya'da bulunan küçük ölçekli bir firmadır.

Oteller için tedarikçi seçim kriterleri ve alternatif tedarikçiler belirlendikten sonra Expert Choice yazılımı kullanılarak hiyerarşik yapılar oluşturulmuştur. Her bir otel için tüm kriterlerin ikili karşılaştırma matrisleri yine aynı yazılım kullanılarak yapılmış ve alternatif tedarikçiler bu kriterlere göre ikili olarak karşılaştırılmıştır.

\subsection{Yıldızlı Otel için Analizler}

Tablo 4.1'de örneği görüldüğü şekilde 5 yıldızlı otel için ikili karşılaştırma matrislerinde tutarlılık oranı 0,1 değerinden küçük olduğundan değerlendirmeler kabul edilebilir aralıkta yer almaktadır.

Tablo 4.1. 5 yıldızlı otel için ana kriterler ikili karşılaştırma matrisi

\begin{tabular}{|l|l|l|l|l|l|l|}
\hline & Esneklik & Fiyat & Kalite & Profil & $\begin{array}{l}\text { Tedarikçi } \\
\text { Illişkileri }\end{array}$ & Teslimat \\
\hline Esneklik & & 5 & 3 & 2 & 2 & 2 \\
\hline Fiyat & & & 3 & 2 & 4 & 3 \\
\hline Kalite & & & 3 & 5 & 3 \\
\hline Profil & & & & & 2 & 2 \\
\hline Tedarikçi İlişkileri & & & & & & 2 \\
\hline Teslimat & Tutarlıl1k: 0,05 & & & & & \\
\hline
\end{tabular}


İkili karşılaştırma matrisinin analizi neticesinde 5 yıldızlı otel için ana kriterlerin önem dereceleri bulunmuştur. Şekil 4.1'de verilen sonuçlara göre en önemli kriter 0,367 değeri ile fiyat olup bunu sırasıyla kalite, profil, teslimat, tedarikçi ilișkileri ve esneklik takip etmiştir. Bu sonuçlar, daha kurumsal tedarikçilerle çalışan 5 yıldızlı otelin bu tedarikçilerin genel olarak miktar, çeşitlilik, acil talep gibi isteklere hızlı cevap verebilmesini olağan karşıladığını, tedarikçi seçiminde en önemli faktörün fiyat veya promosyon olduğunu göstermektedir.

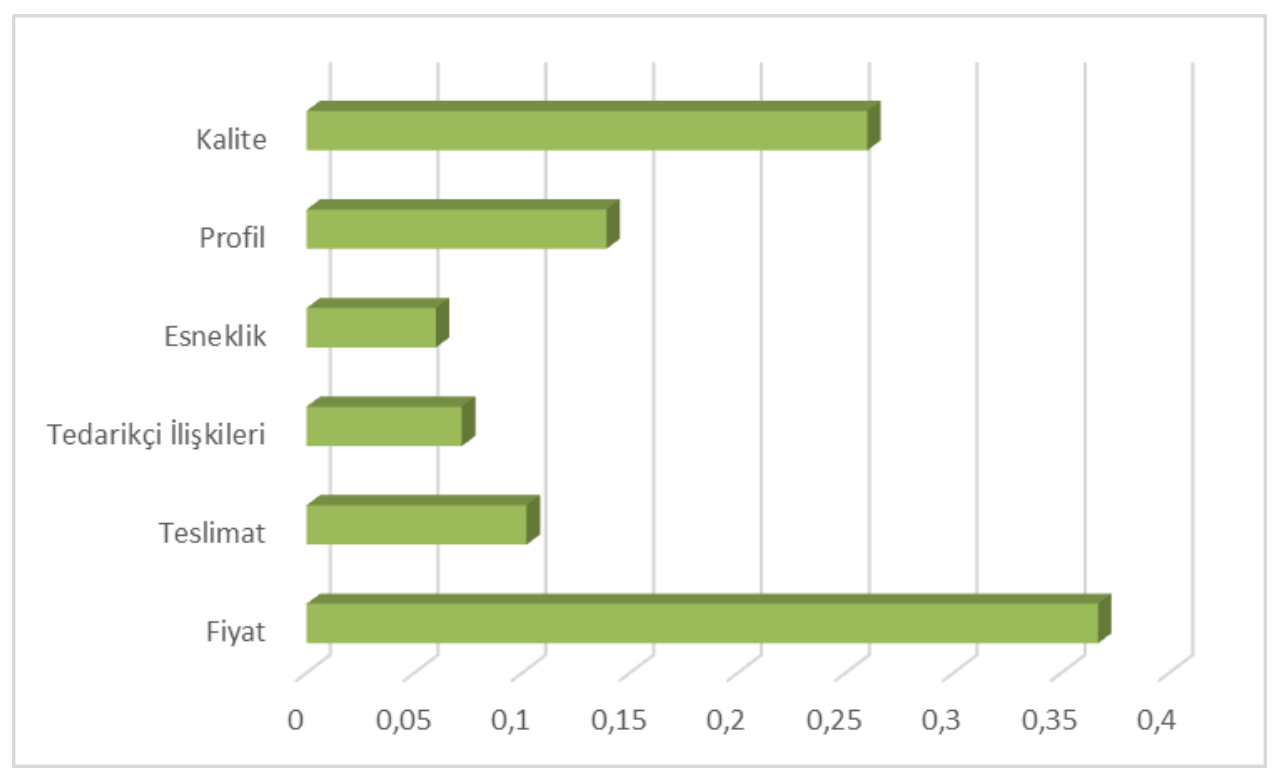

\section{Şekil 4.1: 5 yıldızlı otel ana kriter önem ağırlıkları}

Bir sonraki aşamada alt kriterlerin önem ağırlıkları Expert Choice programı ile belirlenmiştir. Fiyat ve profil için alt kriter yoktur. Teslimat alt kriterlerine bakıldığında en yüksek önem ağırlığına sahip olan doğru miktarda teslimat (0.287) olup diğerleri sırası ile zamanında teslimat (0.245), şartnamelerine uyulması (0.217), doğru yere teslimat (0.143), nakliye yapan araçların uygunluğu (0.108) olarak belirlenmiştir. Tedarikçi ilişkileri ve esneklik ölçütlerinin her bir alt kriterlerinin eşit önem ağırlığına sahip olduğu bulunmuştur. Kalite ölçütüne bakıldığı zaman da önem ağırlığı en yüksek alt kriter ürünün niteliklerine uygun olması (0.236) olup bunu sırasıyla kusurlu ürün oranı (0.191) ve ürünün tesliminde iç ve diş sıcaklığının uygunluğu (0.191), tedarikçinin kalite belgelerine sahip olması (0.170), satış sonrası destek sunulması (0.095), tedarikçinin ilgi düzeyi ve şikayetlerin cevaplanması (0.068) ve uygun ambalajlama yapılması (0.049) olarak bulunmuştur.

Son aşama alternatif tedarikçilerin kendi aralarında alt kriterlere göre ikili karşılaştırılması ve duyarlılık analizidir. Duyarlılık analizi, ana ölçütlerin ağırlıklarının değişen tedarikçilerin sıralamasına etkisini anlamak için yararlıdır. Alternatiflerin karşılaştırılması ve duyarlılık analiz sonuçları Şekil 4.2'de verilmiştir. 


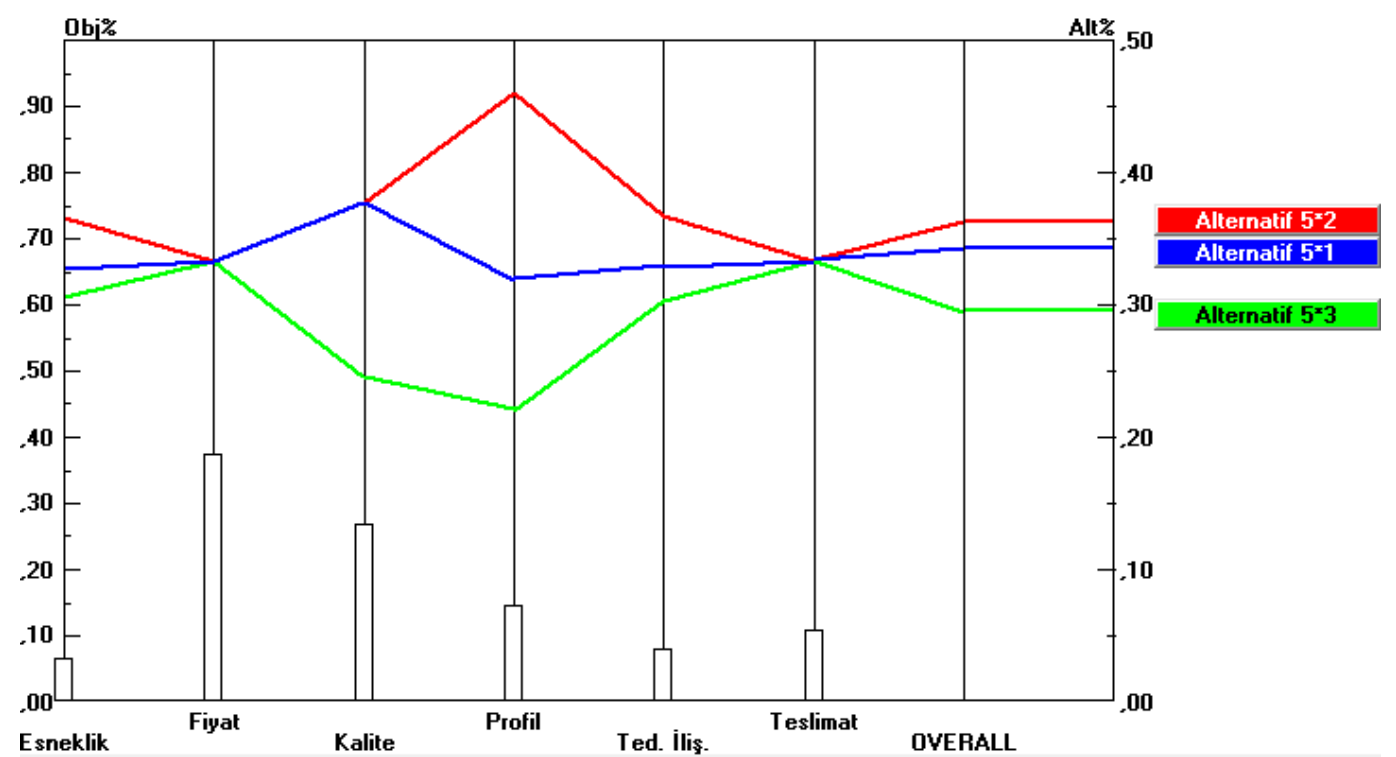

\section{Şekil 4.2: 5 yıldızh otel için performans duyarlıık analizi}

Şekil 4.2'nin sağ y eksenindeki kesişimler alternatif tedarikçilerin sıralamasını vermektedir. Buna göre en iyi tedarikçi 0.362 önem ağırlığına sahip olan Alternatif5*2 olarak bulunmuştur. Sıralamada Alternatif5*1 0.342 değeri ile ikinci, Alternatif5*3 ise 0.296 değeri ile üçüncü sıradadır. Duyarlılık analizi sonucu olan Şekil 4.2'nin sol y ekseni, Şekil 4.1'de olduğu gibi ana kriterlerin alternatif seçimindeki önem derecelerini göstermektedir. Her bir alternatifin ana kriterin göre önceliğini yine să̆ y ekseninden görebiliriz. Buna göre, fiyat ve teslimat ölçütlerine göz önüne alındığı zaman satın alma birimi için tedarikçiler arasında bir fark yoktur. Kalite açısından Alternatif $5 * 3$ en kötü performansı sergilerken diğer iki tedarikçi arasında fark yoktur. Alternatif 5*2'yi en iyi tedarikçi yapan, bariz bir profil farkı, ve bu tedarikçinin esneklik ve tedarikçi ilişkilerinde diğerlerine nazaran daha iyi bir performansının olmasından kaynaklanmaktadır.

\subsection{Yıldızlı Otel için Analizler}

4 yıldızlı otel için ikili karşılaştırma matrisi Tablo 4.2 de verilmiştir. Burada da tutarlılık oranı 0,1 değerine eşit olduğundan değerlendirmeler kabul edilebilir aralıkta yer almaktadır.

Tablo 4.2. 4 yıldızlı otel için ana kriterler ikili karşılaştırma matrisi

\begin{tabular}{|l|l|l|l|l|l|l|}
\hline & Fiyat & Teslimat & $\begin{array}{l}\text { Tedarikçi } \\
\text { Ilişkileri }\end{array}$ & Esneklik & Profil & Kalite \\
\hline Fiyat & & 1 & 2 & 3 & 2 & 1 \\
\hline Teslimat & & & 1 & 3 & 2 & 2 \\
\hline Tedarikçi & & & & 2 & 1 & 2 \\
\hline Esneklik & & & & & 1 & 3 \\
\hline Profil & & & & & & 2 \\
\hline Kalite & Tutarl11k: 0,10 & & & & & \\
\hline
\end{tabular}

4 yıldızlı otel için oluşturulan ikili karşılaştırma matrislerinin analizi sonucunda ana kriterlerin önem dereceleri Şekil 4.3 de verilmiştir. En önemli kriter 0.273 değeriyle kalite olurken bunu sırasıyla esneklik, profil, fiyat, teslimat ve tedarikçi 
ilişkileri takip etmiştir. Tedarikçi ilişkileri kriterinin son sırada yer alması, otelin çalıştığı tedarikçi firmaların local ve kolay ulaşılır olmasından dolayı bu ölçütün diğerlerine nazaran ağırlığının düşük olmasından kaynaklanmaktadır.

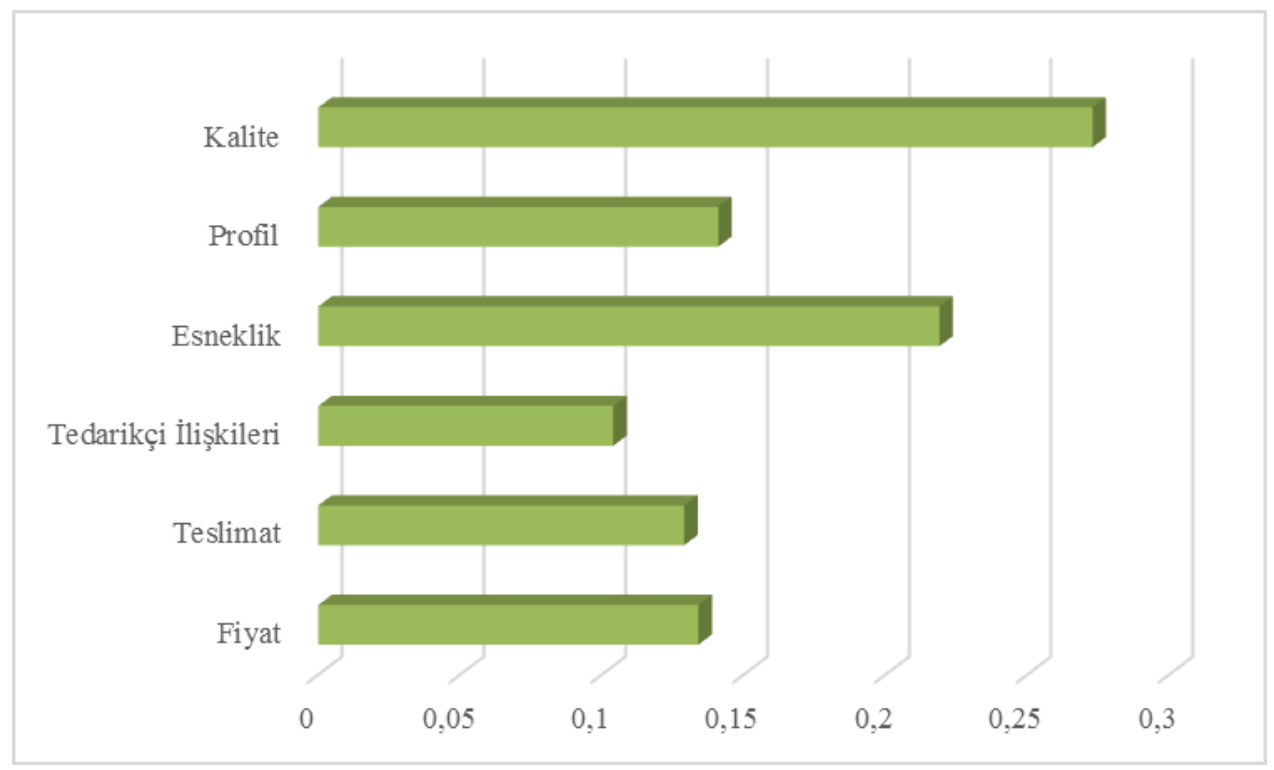

\section{Şekil 4.3: 4 yıldızlı otel ana kriter önem ağırlıkları}

Alt kriterlerin önem ağırlıkları da Expert Choice programı ile belirlenmiştir. 5 yıldızlı otel analizinde olduğu gibi fiyat ve profil için alt kriteri yoktur. Teslimat için en yüksek önem ağırlığına sahip olan alt kriter nakliye yapan araçların uygunluğu (0.319) olup diğerleri sırası ile doğru yere teslimat yapılması (0.235), doğru miktarda teslimat (0.185), zamanında teslimat $(0,136)$ ve teslimat şartnamelerine uyulması $(0.124)$ olarak belirlenmiştir. Tedarikçi ilişkilerinde iletişim kurma kolaylığı ve tedarikçinin anlaşmazlıkları çözümlemesi eşit ağırlığa (0.243) sahipken en yüksek ağılık iletişimde açıklık (0.343), en düşük de işbirliği (0.172) olarak bulunmuştur. Esneklik için en yüksek istenilen çeşitte ürün sunulması (0.468) olup, bunu üründe istenilen değiş̧imleri karşılayabilmesi (0.266), acil ürün isteğine karşıllk verilebilmesi (0.189) ve istenilen miktarda ürün sunulması $(0,078)$ takip etmiştir. Kalitede ise en yüksek ağırlığa ürünün tesliminde iç ve dış sıcaklığının uygunluğu (0.347) alt kriteri sahip olup, bunu tedarikçinin kalite belgelerine sahip olması (0.177), uygun ambalajlama (0170), satış sonrası destek sunulması $(0,102)$, tedarikçinin ilgi düzeyi $(0,078)$, ürünün niteliklerine uygun olması $(0,067)$ ve kusurlu ürün oranı (0.058) izlemiş̧tir.

4 yıldızlı otelin alternatif tedarikçileri için yapılan ikili karşılaştırmalar ve duyarlılık analizi sonuçları Şekil 4.4 de verilmiştir. Bu sonuçlara göre alternatifler arasından 0.564 önem ağırlığına sahip olan Alternatif $4 * 2$ en uygun tedarikçi olarak bulunmuştur. Alternatif4*1 0,245 değeri ile ikinci, Alternatif4*3 de 0,191 değeri ile üçüncü sırayı almıştır. 


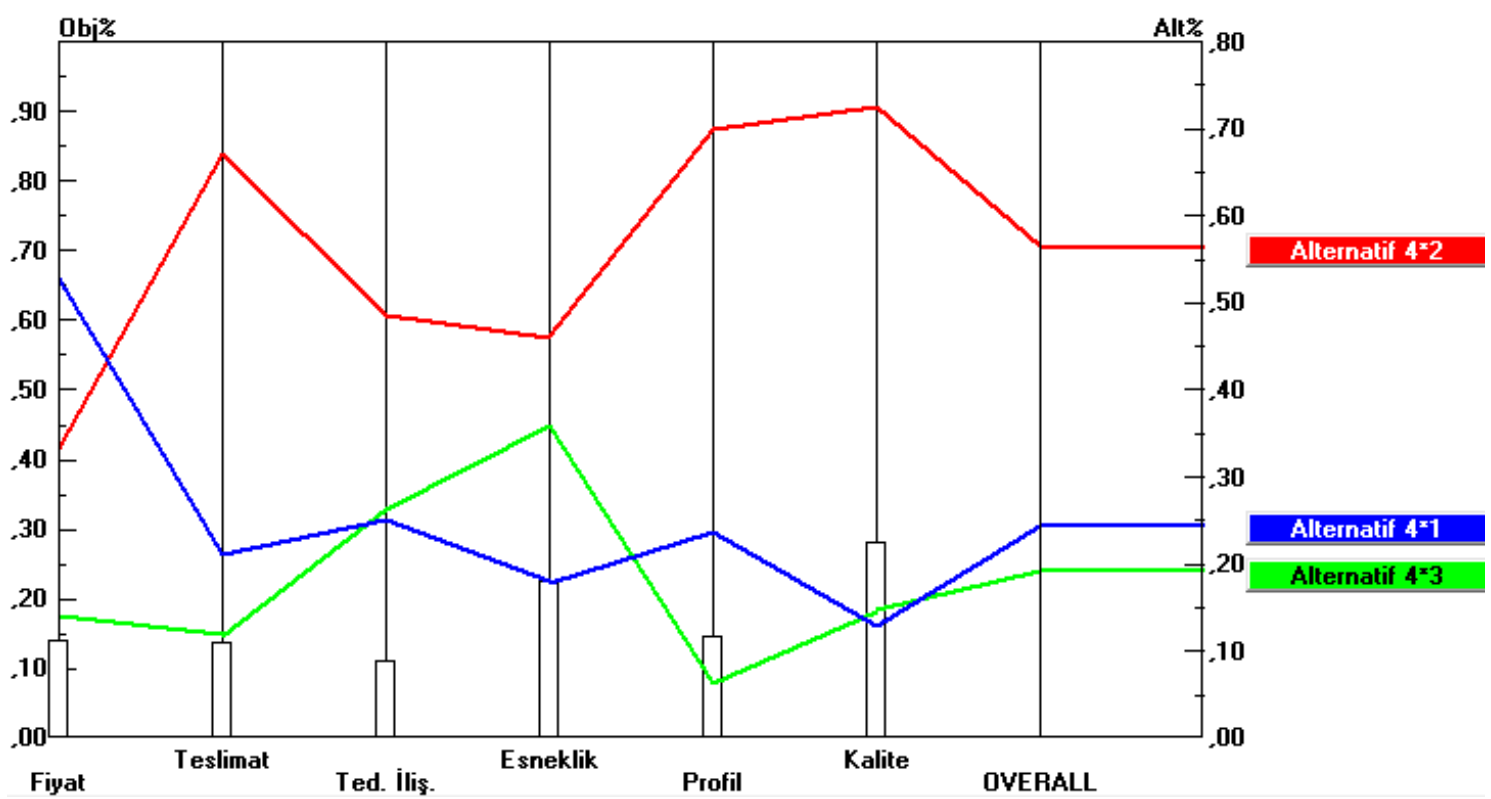

Şekil 4.4. 4 yıldızlı otel için performans duyarlılık analizi

Duyarlılık analizine bakıldığı zaman Alternatif4*2 fiyat hariç bütün ölçütlerde diğer tedarikçilerden daha iyi performans sergilerken en yüksek değeri kalite için almıştır. Alternatif4*1 fiyatta öncelikli tedarikçi olurken kalitede en düşük performansı sergilemiştir.

\section{DEĞERLENDİRME ve SONUÇ}

Uygun tedarikçinin seçilmesi problemi tedarik zinciri yönetiminde önemli konulardan biridir. Müşteri memnuniyeti odaklı çalışan otel işletmelerinde bu seçim zor bir problem haline gelmektedir. Birden fazla değerlendirme kriterinin yer aldığ uygun tedarikçinin seçilmesi problemi çok kriterli karar verme yöntemleri ile çözülebilmektedir. Bu çalışmada çok kriterli karar verme yöntemlerinden AHP yöntemi kullanılmıştır. Analizde kullanılmak üzere literatür araştırması ve yüz yüze mülakatlar sonucunda ana kriterler fiyat, kalite, profil, teslimat, tedarikçi ilişkileri ve esneklik olarak belirlenmiştir. Çalışmada AHP yönteminin algoritması ile çalışan Expert Choice programı kullanılmıştır. Uygulama Alanya turizm sektöründe yer alan otellerde yapılmıştır. 4 yıldızlı ve 5 yıldızlı iki farklı otelde aynı kriterler üzerinden değerlendirme yapılmış olup, bu işletmelerde hizmet farklılıklarından dolayı alternatif tedarikçilerin birbirinden farklı olduğu görülmüştür. 4 yıldızlı otellerin yerel tedarikçilerle çalıştığı, 5 yıldızlı otellerin ise ulusal ve bilinen tedarikçilerle çalıştı̆̆ gözlemlenmiştir.

Ana kriterlerin ağırlıklarına bakıldığı zaman iki işletmede farklılık görünmektedir. 4 yıldızlı otelde ağırlıklar sırasıyla kalite, esneklik, profil, fiyat, teslimat ve tedarikçi ilişkileri olarak bulunmuştur. Bu tip otellerde fiyat, teslimat ve tedarikçi ilişkilerinin öncelikli kriter olmamaları, çalışılan tedarikçilerin yerel olmasından kaynaklanmaktadır. Yerel tedarikçiler, birbirine yakın fiyatlar önerirken, lokasyon itibariyle kolay erişebilmelerinden dolayı bu tedarikçilerle teslimat ve tedarikçi ilişkilerinde sorun yasama olasılı̆̆ı daha azdır. Bundan dolayı, 4 yıldızlı oteller için tedarikçi seçiminde belirleyici iki ana unsur kalite ve esneklik olmuştur.

Kriterlerin önem sırası 5 yıldızlı otel için fiyat, kalite, profil, teslimat, tedarikçi ilişkileri ve esneklik olarak bulunmuştur. Daha lüks olarak bilinen bu tip otellerde kalite kriterinin ikinci sırada yer alması, çalışılan tedarikçilerin ulusal olması ve bu tedarikçilerin daha standart kalitede ürünler sunmalarından kaynaklanmaktadır. 5 yıldızlı otellerde fiyat kriterinin öncelikli olmasının sebebi bu tip otellerin kalite ve hizmet standartları birbine yakın olduğundan rakiplerine ancak maliyeti düşürerek fark atacaklarını düşünmelerinden kaynaklanmaktadır. 
Profil kriteri hem 4 yıldızlı hem de 5 yıldızlı otelde aynı derecede öneme sahip olup üçüncü sırada yer almıştır. Esneklik kriteri sıralamasının bu otellerde farklı olmasının sebebi ise yine tedarikçilerin ulusal olup olmamasından kaynaklanmaktadır. Ulusal firmalar, ürün çeşitliliği ve üretim kapasitesi olarak lokal firmalara göre daha esnek davranabilmektedirler. Teslimat ve tedarikçi ilişkileri 5 yıldızlı otellerde daha önemli olduğu görülmektedir. Bunu sebebi, teslimatta meydana gelecek aksaklıkların, 5 yıldızlı otellerde hizmet standartlarının daha yüksek olmasından dolayı 4 yıldızlı otellere göre daha zor telafi edilebilir olmasındandır. Bu tip otellerin çalıştıkları ulusal tedarikçilerin yerel tedarikçilere nazaran daha zor ulaşılabilir olmaları tedarikçi ilişkilerinin daha önemli bir kriter olmasına neden olmuştur.

Aynı sektörde olmalarına rağmen 4 ve 5 yıldızlı otellere hizmet standartları ve alternatif tedarikçilerin farklı olması tedarikçi secim kriterlerin önem derecelerinde farklılık oluşmasına neden olmuştur. Kalite kriteri her iki tip işletmede de ilk iki sırada yer alırken, 4 yıldızlı otel için esneklik, 5 yıldızlı otel için de fiyat diğer önemli kriter olmuştur. Bundan sonraki çalışmalar, sektörde kullanılabilecek tedarikçi seçme kriterlerini genişletebilir ve AHP uygulamasını daha fazla kriterle gerçekleştirebilir.

\section{KAYNAKÇA}

ABDULMUMIN, A.G. (2005). "Instrumental and Interpersonal Determinants of Relationship Satisfaction and Commitment in Industrial Markets", Journal of Business Research, 58 (2005) 619- 628.

ADA, E., KAZANÇOĞLU, Y., ARACIOĞLU, B. (2005). "Stratejik Rekabet Üstünlüğü Sağlamada Tedarikçi Seçiminin Analitik Hiyerarşik Süreç ile Gerçekleştirilmesi”, V. Ulusal Üretim Araştırmaları Sempozyumu, İstanbul Ticaret Üniversitesi, 605-611.

ALIOĞLLU, E., 2006, Belediyelerde performans ölçümü için çok ölçütlü bulanık bir model önerisi, Yüksek Lisans Tezi, İstanbul Teknik Üniversitesi Fen Bilimler Enstitüsü, İstanbul.

BENYOUCEF L., DINNG H., XIE X., (2003). Supplier Selection Problem: Selection Criteria and Methods, s.3-4.

ÇAKIROĞLU, T., (2009). Analitik Hiyerarşi Süreci Yaklaşımı İle Tedarikçi Seçim Kriterlerinin Belirlenmesi: Trabzon Organize Sanayi Bölgesi Örneği, Yüksek Lisans Tezi, Karadeniz Teknik Üniversitesi Sosyal Bilimler Enstitüsü, Trabzon.

DICKSON, G.W. (1966), "An analysis of vendor selection systems and decisions", Journal of Purchasing 2, 517.

DÜNDAR, S. (2008). "Ders Seçiminde Analitik Hiyerarşi Proses Uygulaması”. Süleyman Demirel Üniversitesi İktisadi ve İdari Bilimler Fakültesi Dergisi, 13:217-226.

ECER, F., KÜÇÜK, O. (2008). “Tedarikçi Seçiminde Analitik Hiyerarşi Yöntemi ve Bir Uygulama”. Atatürk Üniversitesi Sosyal Bilimler Enstitüsü Dergisi, 11(1).

ERASLAN, E., ALGÜN, O. (2005). “İdeal Performans Değerlendirme Formu Tasarımında Analitik Hiyerarşi Yöntemi Yaklaşımı”. Gazi Üniversitesi Mühendilik Mimarlık Fakültesi Dergisi, 20:95-106.

ERDEM, G. (2003). "Tedarik Zinciri Yönetimi Uygulamalarının Benimsenmesinin, Tedarik Zinciri ve İşletme Performansına Etkisi”. Yüksek Lisans Tezi, Hitit Üniversitesi Sosyal Bilimler Enstitüsü, Çorum.

GÜNER, H. (2005). "Bulanık AHP ve Bir İşletme için Tedarikçi Seçimi Problemine Uygulanması". Yüksek Lisans Tezi, Pamukkale Üniversitesi Fen Bilimleri Enstitüsü, Denizli.

GÜNER, H., MUTLU, Ö. (2005). "Bulanık AHP İle Tedarikçi Seçim Problemi ve Bir Uygulama”. V. Ulusal Üretim Araştırmaları Sempozyumu, İstanbul Ticaret Üniversitesi, 25-27 Kasım.

KAPAR, K. (2013). “Bir Üretim İşletmesinde Analitik Hiyerarşi Süreci İle Tedarikçi Seçimi”. Dokuz Eylül Üniversitesi İktisadi ve İdari Bilimler Fakültesi Dergisi, 28:197-231. 
KARAGÖZ, S. (2009). “Tedarik Zinciri Yönetiminde Tedarikçi Seçimi ve AHP ile Uygulanması”. Yüksek Lisans Tezi, Pamukkale Üniversitesi Sosyal Bilimler Enstitüsü, Denizli.

KÜÇÜK, O., ECER, F. (2008). "İmalatçı İşletmelerde Uygun Tedarikçi Seçimi: Analitik Hiyerarşi Yöntemi ile Bir Kobi Uygulaması", İktisadi ve İdari Bilimler Dergisi, 22:435-450.

LIU, F.H., HAI, H.L. (2005). “The Voting Analytic Hierarchy Process Method for Selecting Supplier”, Int. J. Production Economics, 97, 308-317.

ÖMÜRBEK, N., ŞIMŞEK, A. (2012). “Üniversitesi Öğrencilerinin Cep Telefonu Tercihlerinin Analitik Hiyerarşik Prosesi ile Belirlenmesi”. Niğde Üniversitesi İ̈BF Dergisi, 5:116-132.

ÖZ, E., BAYKOÇ Ö. F. (2004). “Tedarikçi Seçimi Problemine Karar Teorisi Destekli Uzman Sistem Yaklaşımı”, Gazi Üniversitesi Mühendislik Mimarlık Fakültesi Dergisi, 19:275-286.

ÖZER, S. (2005). "Mermer Fabrikaları İçin En İyi Tesis Yeri Seçimi”. Yüksek Lisans Tezi, Eskişehir Osmangazi Üniversitesi Fen Bilimleri Enstitüsü, Eskişehir.

ÖZGÜL, Ö. (2006). "Bir İşletme için TOPSIS ve AHP Yöntemi ile ERP Yazılımının Seçimi". Yüksek Lisans Tezi, Sakarya Üniversitesi Fen Bilimleri Enstitüsü, Sakarya.

PRAHINSKI C., BENTON W. C. (2004). "Supplier Evaluations: Communication Strategies to İmprove Supplier Performance". Journal of Operations Management, 22:39-62.

ROA, C.P., KISER, G.E. (1980). "Educational Buyers' Perceptions of Vendor Attributes". Journal of Purchasing and Materials Management 16:25-30.

SAAT, M. (2000). "Çok Amaçlı Karar Vermede Bir Yaklaşım Analitik Hiyerarşi Yöntemi”, Gazi Üniveristesi İ.İ.B.F. Dergisi, 2:149-162.

SAATY, T. L. (2000). "Fundamentals of Decision Making and Priority Theory with the Analytic Hierarchy Process". RWS Publications, Pittsburgh, USA.

ŞEN, E. (2006). “Kobi'lerin Uluslararası Rekabet Güçlerini Artırmada Tedarik Zinciri Yönetiminin Önemi”, İgeme Yayınları, Ankara.

TOKSARI, M. (2007). “Analitik Hiyerarşi Prosesi Yaklaşımı Kullanılarak Mobilya Sektörü İçin Ege Bölgesinde Hedef Pazarın Belirlenmesi”. Yönetim ve Ekonomi Dergisi, 14:171-180 .

TOPEL, A. (2006). “Analitik Hiyerarşik Prosesinin Bulanık Mantık Ortamındaki Uygulamaları-Bulanık Analitik Hiyerarşi Prosesi”. Yüksek Lisans Tezi, İstanbul Üniversitesi Sosyal Bilimler Enstitüsü, İstanbul.

TURGUT, Ç. (2015). "Tedarik Zinciri Yönetiminde AHP ve Bulanık AHP Yöntemi Kullanılarak Tedarikçilerin Performansının Ölçülmesi, Yeni Yöntem Önerileri ve Uygulamaları”, Yüksek Lisans Tezi, Dokuz Eylül Üniversitesi Sosyal Bilimler Enstitüsü, İzmir.

WEBER, C. A., CURRENT, J. R., BENTON, W. C., (1991). "Vendor Selection Criteria And Methods", European Journal of Operational Research, 50:2-18.

YU, X., GUO, S., GUO, J., HUANG, X, (2011), "Rank B2C E-Commerce Websites in E-Alliance Based On AHP and Fuzzy TOPSIS”, Expert Systems with Applications, 38:3550-3557. 